\title{
EFFECTS OF NITROGEN APPLICATION ON BIOMASS ACCUMULATION, REMOBILIZATION, AND SOIL WATER CONTENTS IN A RAINFED WHEAT FIELD
}

\author{
Wenxue Duan ${ }^{1,2}$, Zhenwen $\mathrm{Yu}^{1}$, Yongli Zhang ${ }^{1, *}$, Dong Wang $^{1}$, Yu Shi ${ }^{1}$, Zhenzhu Xu ${ }^{3}$ \\ ${ }^{1}$ Key Laboratory of Crop Ecophysiology and Cultivation, Ministry of Agriculture, Shandong Agricultural \\ University, Tai'an, CHINA \\ ${ }^{2}$ Crop Research Institute, Shandong Academy of Agricultural Sciences, Jinan, CHINA \\ ${ }^{3}$ State Key Laboratory of Vegetation and Environmental Change, Institute of Botany, Chinese \\ Academy of Sciences, Beijing, CHINA \\ Corresponding author: zhangyl2012sdau@163.com
}

Received: 16.01 .2013

\begin{abstract}
This study examined the effects of different levels of $\mathbf{N}$ fertilization on dry matter accumulation and remobilization, and soil water contents in a rainfed winter wheat field. The experiments were carried out during growth seasons in 2009 - 2012 in a hilly region in Shandong Province, China. The $\mathbf{N}$ rates applied were 0 (N0, the control), 90 (N1), 120 (N2), 150 (N3), 180 (N4), and 210 (N5) kg $\mathbf{N}^{\text {ha }}{ }^{1}$. Our results showed that $N$ fertilization significantly increased dry matter accumulation and post-anthesis assimilates compared with controls. At anthesis, total above-ground biomass increased significantly with increasing $\mathbf{N}$ rate up to $150 \mathrm{~kg}$ $h^{1}{ }^{1}$ and then leveled off in the $2009-2010$ and $2011-2012$ growth seasons. However, the biomass in the 2010 - 2011 growth season did not vary with different $\mathrm{N}$ rates. At maturity, the accumulation of dry matter in vegetative organs significantly increased with increasing $N$ rate up to $150 \mathrm{~kg} \mathrm{ha}^{1}$ and then leveled off in all growth seasons. Of all the treatments, $\mathrm{N} 3$ and $\mathrm{N} 4$ had relatively higher total above-ground biomass at maturity. In contrast, dry matter remobilization efficiency showed a declining trend under increasing $\mathbf{N}$ rate. The higher post-anthesis assimilates and the contribution of pre-anthesis assimilates to grains were obtained at $\mathrm{N}$ rates of 150 and $180 \mathrm{~kg} \mathrm{ha}^{1}$ in all growth seasons. Soil water contents in $0-120,0-100$, and $40-160 \mathrm{~cm}$ soil layers during each growth season decreased significantly with increasing $N$ rate up to $150 \mathrm{~kg} \mathrm{ha}{ }^{1}$. The maximum grain yields were obtained under $N$ rate of $150 \mathrm{~kg} \mathrm{ha}^{1}{ }^{1}$ in all growth seasons, with the highest grain yield being $7160.8 \mathrm{~kg} \mathrm{ha}{ }^{1}$ in the $2011-2012$ growth season. Our results suggested that $\mathrm{N}$ fertilization at $150 \mathrm{~kg} \mathrm{~N}^{\mathrm{N}}$ ha ${ }^{1}$ was optimal for grain production via promoting above-ground biomass and soil water consumption in deep soil layers. These results should help provide guidance for $\mathbf{N}$ fertilization management for optimal and sustainable wheat production in the said region.
\end{abstract}

Keywords: Dry matter accumulation, dry matter remobilization, grain yield, $\mathrm{N}$ application rate, rainfed winter wheat, soil water content,.

\section{INTRODUCTION}

Shandong Province, located in the Yellow River and Huai River Valleys, is a major wheat-growing region that accounted for $14.7 \%$ of total harvest area and $17.9 \%$ of total wheat production in China in 2009 (China Agriculture Statistical Report, 2010). However, approximately 1.3 million ha of wheat planting farmland in Shandong is rainfed, accounting for one third of total wheat planting area in this province (Wang et al., 2003). Nitrogen fertilization is one of the most effective means to promote wheat growth and improve grain yield, especially in rainfed dry farmland (Holger et al., 1997; Hao et al., 2007; Ryan et al., 2012). The optimum $\mathrm{N}$ fertilization rate depends on a variety of factors including residual $\mathrm{N}$ in soil, wheat cultivars, and local climate conditions, and may differ in different dryland areas. Ryan et al. (1998) reported that $40 \mathrm{~kg} \mathrm{~N}^{-1}$ was adequate for maximum dryland wheat yield in most areas of North Africa. Basso et al. (2010) recommended $60 \mathrm{~kg} \mathrm{~N} \mathrm{ha}{ }^{1}$ for rainfed Mediterranean farmland considering both decreased nitrogen fertilizer losses and increased wheat yield. Halvorson et al. (2004) reported that $84 \mathrm{~kg} \mathrm{~N} \mathrm{ha}^{1}$ was optimal for no-till dryland in the central Great Plains under wheat-summer crop-fallow rotation. Li et al. (2000) showed that $138 \mathrm{~kg} \mathrm{~N} \mathrm{ha}{ }^{1}$ was adequate for optimum wheat yield in a loess hilly dryland in the western part of Henan Province. However, the appropriate $\mathrm{N}$ rate for optimal water use efficiency and grain yield of winter 
wheat in the rainfed hilly areas in Shandong Province has rarely been studied.

In wheat plants, assimilates to grains originate from both current assimilation and remobilization of assimilates stored in vegetative organs (Austin et al., 1980; Pheleung and Siddique, 1991; Schnyder, 1993). Nitrogen can affect dry matter accumulation and remobilization after anthesis (Mainard and Jeuffroy, 2001; Ferrise et al., 2010). However, the findings of $\mathrm{N}$ fertilization studies on those have been inconsistent. Wang et al. (2010) found that maximum dry matter remobilization efficiency (DMRE) was obtained at different $\mathrm{N}$ rates in different genotypes of winter wheat. Zhang et al. (2010) reported that maximum post-anthesis dry matter accumulation was obtained at a relatively lower $\mathrm{N}$ rate. In addition, Bahrani et al. (2011) reported that dry matter remobilization (DMR) and DMRE increased with increasing $\mathrm{N}$ rate up to $80 \mathrm{~kg} \mathrm{~N}$ ha but decreased at higher $\mathrm{N}$ rates in the Mediterranean climate. Similarly, Zhang et al. (2010) showed that DMRE decreased with $\mathrm{N}$ rate after $\mathrm{N}$ rates exceeded $94 \mathrm{~kg} \mathrm{~N}$ ha ${ }^{1}$ in the Tai Lake region of China. These inconsistent results may be due to the different cultivar properties, soil fertility, and growing environments investigated. Although there have been a few studies on $\mathrm{N}$ fertilization for winter wheat production under climate conditions in Shandong Province of China, the effects of $\mathrm{N}$ rate on biomass accumulation and translocation in winter wheat under rainfed conditions in Shandong Province have rarely been explored.

In Shandong Province, annual rainfall ranges from $550 \mathrm{~mm}$ to $650 \mathrm{~mm}$, and rainfall during the growth season of winter wheat ranges from $162 \mathrm{~mm}$ to $310 \mathrm{~mm}$, which is significantly lower than the estimated wheat water requirements in Shandong Province (Wang et al., 2007). The annual yield of rainfed wheat significantly changes because of the different patterns in rainfall amount and distribution during the growth season. This significant change is not beneficial for maintaining and improving the total wheat production in this region. Research has shown that nitrogen fertilization also promoted wheat to utilize more soil water and improve its water use efficiency (WUE), especially under rainfed conditions (Holger et al., 1997). The effects of $\mathrm{N}$ rate on water use in wheat under irrigation conditions have been widely reported (Garabet et al., 1998; Timsina et al., 2001; Li et al., 2004). However, how $\mathrm{N}$ rate affects WUE in wheat under rainfed conditions, especially in the Yellow River and Huaihe River areas of China, remains largely unexplored.
The amount and timing of nitrogen fertilization needed for optimum crop yields are dictated by the potential yields for a specific environment, that is, climate, soils, crop varieties and management (Ryan et al., 2012). In the rainfed hilly of west Henan Province, China, nitrogen is applied before sowing at a recommended rate of $138 \mathrm{~kg} \mathrm{~N} \mathrm{ha}^{1}$ (Li et al., 2000). Chen et al. (2010) reported that $120 \mathrm{~kg} \mathrm{~N}^{\mathrm{a}^{1}}$ as a basal dressing would help maintain wheat yield and improve water use efficiency in the Weibei dryland of Loess Plateau. According to Li et al. (2011), top dressing of $30 \mathrm{~kg} \mathrm{~N} \mathrm{ha}{ }^{1}$ on basic nitrogen application of $165 \mathrm{~kg} \mathrm{~N}$ ha $^{1}$ are important measures to increase yield of winter wheat in rainfed regions of southern Shanxi Province. In rainfed areas of middle Shandong Province, drought frequently occurs at revival and jointing stages of wheat growth (Wang et al., 2013), and farmers did not have the habit of fertilizer topdressing. Most previous studies tested fewer than five $\mathrm{N}$ rates to assess the effects of $\mathrm{N}$ rate on wheat production in rainfed dryland areas (Ehdaie and Waines, 2001; Halvorson et al., 2004; Ercolia et al., 2008). In the present study, we conducted a field experiment in a rainfed hilly dryland of Shandong Province to investigate the effects of $\mathrm{N}$ fertilization before sowing on winter wheat. The effects of six gradient $\mathrm{N}$ rates on biomass accumulation, remobilization, and water use characteristics were investigated. Our results provided an estimate of optimal level of nitrogen fertilization to help maintain high and stable winter wheat production in the said region.

\section{MATERIALS AND METHODS}

\section{Experimental site}

The field experiment was conducted in a hilly rainfed area in Bianhe Village (36 $\square 7 \square \mathrm{N}, 118 \square 2 \square \mathrm{E}$ ), Linzi, Shandong Province, China, during the growth seasons in 2009 - 2012. The average annual temperature and rainfall in the study area are $13.0 \square \mathrm{C}$ and $746.8 \mathrm{~mm}$, respectively, with $60 \%-70 \%$ of rainfall occurring in the summer from June to August. The top $20 \mathrm{~cm}$ soil layer in the experimental field before sowing contained $12.1 \mathrm{~g} \mathrm{~kg}^{-1}$ of organic matter, $1.0 \mathrm{~g} \mathrm{~kg}^{1}$ of total $\mathrm{N}, 73.5 \mathrm{mg} \mathrm{kg}^{1}$ of alkali-hydrolyzable $\mathrm{N}, \quad 27.0 \mathrm{mg} \quad \mathrm{kg}^{1}$ of available phosphate, and $115.8 \mathrm{mg} \mathrm{kg}^{1}$ of available potassium during the growth seasons in 2009 - 2012. The precipitation data in different periods of wheat growth are shown in Table 1.

Table 1. Rainfall during different wheat growth periods during the 2009-2012 growth seasons

\begin{tabular}{lllllll}
\hline $\begin{array}{l}\text { Growth } \\
\text { seasons }\end{array}$ & $\begin{array}{l}\text { Sowing to } \\
\text { pre-winter }\end{array}$ & $\begin{array}{l}\text { Pre-winter to } \\
\text { revival }\end{array}$ & $\begin{array}{l}\text { Revival to } \\
\text { jointing }\end{array}$ & $\begin{array}{l}\text { Jointing to } \\
\text { anthesis }\end{array}$ & $\begin{array}{l}\text { Anthesis to } \\
\text { maturity }\end{array}$ & Total \\
\hline $2009-2010$ & 57.9 & 37.7 & 35.6 & 7.9 & 99.8 & 238.9 \\
$2010-2011$ & 5.0 & 0.0 & 20.0 & 9.5 & 71.1 & 105.6 \\
$2011-2012$ & 105.6 & 12.7 & 23.2 & 25.1 & 11.6 & 178.2 \\
\hline
\end{tabular}




\section{Experimental design and crop management}

The winter wheat cultivars Jimai 22 (the most widely planted cultivar in the Yellow River and Huai River Valleys of China), Shannong 16 (a widely planted dryland cultivar in Shandong Province), and Yannong 0428 (another widely planted dryland cultivar in Shandong Province) were studied in the three wheat growth seasons from 2009 - 2012, respectively. Six N rates were applied before sowing in each growth season: 0 (N0), 90 (N1), 120 (N2), 150 (N3), 180 (N4), and 210 (N5) kg N ha ${ }^{1}$. Each treatment was replicated three times in plots measured $3 \mathrm{~m} \square 6 \mathrm{~m}$ each in a completely randomized block design.

Wheat seeds were sown on 3 October 2009, 4 October 2010, and 5 October 2011, and the plants were harvested on 15 June 2010, 11 June 2011, and 7 June 2012, respectively. Fertilizers applied in each growth season included urea $(46.4 \% \mathrm{~N})$, calcium triple superphosphate $\left(\begin{array}{lll}46 \% & \mathrm{P}_{2} \mathrm{O}_{5}\end{array}\right)$, and potassium sulfate $\left(50 \% \mathrm{~K}_{2} \mathrm{O}\right)$. In each growth season, fixed amounts of $\mathrm{P}_{2} \mathrm{O}_{5}\left(150 \mathrm{~kg} \mathrm{ha}^{1}\right)$ and $\mathrm{K}_{2} \mathrm{O}\left(150 \mathrm{~kg} \mathrm{ha}{ }^{1}\right)$ were added with varying amounts of nitrogen fertilizer before sowing. The seeds were sown at a distance of $0.25 \mathrm{~m}$ per row and the seedling density was maintained at 225 plants per $\mathrm{m}^{2}$ at the four-leaf stage. Irrigation was not performed in any growth season throughout the experiment. Other field managements followed those for general field production.

\section{Measurements of variables}

Dates of plant anthesis and maturity were recorded. Anthesis was defined as when anthers of the central spikelets of $50 \%$ of ears in a plot had extruded, whereas maturity was defined as when most of the ears in the plot showed complete loss of green color. At times of anthesis and maturation, 30 randomly selected culms were cut at the ground level and samples of stems + sheaths, leaves, glumes (spike axis and kernel husks), and grains (only at harvest) were collected. All plant samples were oven-dried at $75 \square \mathrm{C}$ to constant weight for determination of above-ground biomass (Xu et al., 2005).

Various parameters of dry matter accumulation and remobilization were calculated using formula described by Papakosta and Gagianas (1991) and Arduini et al. (2006):

DMR during Grain Filling = Dry Matter of Vegetative Plant Parts at Anthesis $\square$ Dry Matter of Vegetative Plant Parts at Maturity

This formula is valid under the assumption that all dry matter lost from vegetative parts of the plant is translocated to the developing grain, as loss of dry matter owing to plant respiration during grain filling is so little that it is neglected.

DMRE $=($ DMR $/$ Dry Matter of the Aerial Plant Part at Anthesis) $\square 100$

The post-anthesis dry matter accumulation was calculated as the difference between the dry matter of the aerial parts of a plant at physiological maturity and that at anthesis:

Contribution of Post-anthesis Dry Matter Assimilate to Grain $=$ (Post-anthesis Dry Matter Accumulation / Dry Matter of Grain at Maturity) $\square 100$

Evapotranspiration (ET) was calculated using the water balance equation (Corbeels et al. 1998; Miranzadeh et al., 2011):

$$
\mathrm{ET}=\left(P+I+S_{\mathrm{G}}\right)-(\mathrm{D}+\mathrm{R})-\square S,
$$

where $P$ is the growth season rainfall $(\mathrm{mm}), I$ is irrigation $(\mathrm{mm}), S_{\mathrm{G}}$ is groundwater contribution to plant available water $(\mathrm{mm}), D$ is downward drainage out of the root zone $(\mathrm{mm}), R$ is surface runoff $(\mathrm{mm})$, and $\square S$ is the change in soil water stored in the upper $200 \mathrm{~cm}$ of soil between sowing and maturity $(\mathrm{mm})$. In this experiment, the groundwater was $10 \mathrm{~m}$ below the surface and runoff was prevented from the experimental plots, such that $S_{\mathrm{G}}$, $D$, and $R$ were all negligible. In addition, $I$ was assigned a zero value since irrigation was not performed throughout the growth period in this experiment.

Soil water content (SWC) in every $20-\mathrm{cm}$ soil layer up to a depth of $200 \mathrm{~cm}$ was measured by the oven drying method, which was used to estimate the soil water consumption $(\square S)$. Soil core samples were randomly collected using a $50 \mathrm{~mm}$ diameter steel sampling tube. Soil cores were weighed, oven-dried at $105 \square \mathrm{C}$ for $48 \mathrm{~h}$, and re-weighed to determine the gravimetric water content Gravimetric water content was converted to volumetric water units using measured bulk densities for the ten soil layers, respectively. Measurements of soil water contents were taken immediately before seeding and again immediately after harvesting (Yule, 1984; Gan et al., 2000).

WUE was calculated based on the following equation (Corbeels et al., 1998):

\section{WUE $=$ Grain Yield $/$ ET}

At maturity, plant samples were collected from two 1-m rows adjacent to each other in the center of each plot. The number of spikes per square meter was obtained from the collected samples (Hassan and Bedreldin, 1996; Villegas et al., 2010). The average number of grains per spike was determined from 20 randomly selected spikes (Hossein and Mohammand, 2009). The thousand-kernel weight was calculated from a randomly selected sample of 500 grains from each plot (Villegas et al., 2010). Grain yield was calculated based on $3-\mathrm{m}^{2}$ harvest areas in each plot and expressed at $12.5 \%$ grain moisture (Xue et al., 2006).

\section{Statistical analysis}

Statistical analysis was performed using SPSS Version 13.0 for Windows (SPSS, Chicago, Illinois, USA). All data presented were means over three replicates. Differences between means were analysed by ANOVA. The least significant difference test was used to compare differences in means among treatments at the 0.05 probability level. 


\section{RESULTS}

\section{Dry matter accumulation and partitioning at anthesis and maturity}

Dry matter accumulation and partitioning into different parts at anthesis and maturity varied with $\mathrm{N}$ rates in each growth season (Table 2). At anthesis, the total above-ground biomass significantly increased with increasing $\mathrm{N}$ rate up to $150 \mathrm{~kg} \mathrm{ha}^{1}$ and then leveled off in growth seasons of $2009-2010$ and $2011-2012$. However, the total above-ground biomass at anthesis did not vary with $\mathrm{N}$ rates in 2010 - 2011, during which the amount of rainfall before anthesis was lower than those in the other two growth seasons. Our results showed that increasing $\mathrm{N}$ rate up to $150 \mathrm{~kg} \mathrm{ha}^{1}$ significantly improved dry matter accumulation at anthesis in growth seasons that had more rainfall before anthesis.

Table 2. Dry matter accumulation and partition $\left(\mathrm{mg} \mathrm{culm}^{-1}\right)$ in different organs at anthesis and maturity under different $\mathrm{N}$ treatments during the 2009-2012 growth seasons

\begin{tabular}{|c|c|c|c|c|}
\hline \multirow{2}{*}{ Treatment } & \multirow{2}{*}{$\begin{array}{c}\text { Anthesis } \\
\text { Total } \\
\end{array}$} & \multicolumn{3}{|c|}{ Maturity } \\
\hline & & Vegetative & Grain & Total \\
\hline \multicolumn{5}{|l|}{ 2009-2010 } \\
\hline No & $1287.11 \mathrm{~b}$ & $1011.44 \mathrm{c}$ & $836.11 \mathrm{c}$ & $1847.56 \mathrm{~d}$ \\
\hline N1 & $1317.67 \mathrm{~b}$ & $1025.67 \mathrm{c}$ & $880.44 \mathrm{~b}$ & $1906.11 \mathrm{c}$ \\
\hline N2 & $1347.78 b$ & $1049.33 c$ & $885.33 b$ & $1934.67 \mathrm{c}$ \\
\hline N3 & $1414.11 \mathrm{ab}$ & $1114.44 \mathrm{a}$ & $990.22 \mathrm{a}$ & $2104.67 \mathrm{a}$ \\
\hline N4 & $1427.00 \mathrm{a}$ & $1131.56 \mathrm{a}$ & $984.67 \mathrm{a}$ & $2116.22 \mathrm{a}$ \\
\hline N5 & 1437.33a & $1143.22 \mathrm{a}$ & $872.89 \mathrm{~b}$ & $2016.11 b$ \\
\hline \multicolumn{5}{|l|}{$2010-2011$} \\
\hline No & $1000.89 \mathrm{~b}$ & $790.22 \mathrm{c}$ & $663.89 c$ & $1454.11 \mathrm{c}$ \\
\hline N1 & $1230.33 \mathrm{a}$ & $922.11 b$ & $861.22 b$ & $1783.33 b$ \\
\hline N2 & $1222.56 \mathrm{a}$ & $937.89 \mathrm{~b}$ & $872.56 b$ & $1810.44 b$ \\
\hline N3 & $1263.22 \mathrm{a}$ & $1074.11 \mathrm{a}$ & $951.78 \mathrm{a}$ & $2025.89 a$ \\
\hline N4 & $1249.44 \mathrm{a}$ & $1054.67 \mathrm{a}$ & $933.89 \mathrm{a}$ & $1988.56 \mathrm{a}$ \\
\hline N5 & $1247.00 \mathrm{a}$ & $1062.33 \mathrm{a}$ & $916.56 \mathrm{a}$ & $1978.89 \mathrm{a}$ \\
\hline \multicolumn{5}{|l|}{ 2011-2012 } \\
\hline No & $1223.11 \mathrm{~d}$ & $910.67 d$ & $752.56 \mathrm{c}$ & $1663.22 \mathrm{c}$ \\
\hline N1 & $1420.44 \mathrm{c}$ & $1088.67 \mathrm{c}$ & $1044.44 b$ & $2133.11 b$ \\
\hline $\mathrm{N} 2$ & $1428.44 \mathrm{c}$ & $1101.56 \mathrm{c}$ & $1055.89 b$ & $2157.44 b$ \\
\hline N3 & $1582.67 \mathrm{~b}$ & $1207.56 b$ & $1122.89 a$ & $2330.44 a$ \\
\hline N4 & $1588.00 \mathrm{ab}$ & $1224.56 b$ & $1112.56 \mathrm{a}$ & $2337.11 \mathrm{a}$ \\
\hline N5 & $1664.67 \mathrm{a}$ & $1302.22 \mathrm{a}$ & $1037.67 \mathrm{~b}$ & $2339.89 a$ \\
\hline
\end{tabular}

Values are means over three replicates. Values in the same column with different letters in each growth season are significantly different $(n=3 ; P<0.05)$.

At maturity, the accumulation of dry matter in vegetative organs significantly increased with increasing $\mathrm{N}$ rate up to $150 \mathrm{~kg} \mathrm{ha}^{1}$ and leveled off under higher $\mathrm{N}$ rates in all growth seasons. Dry matter accumulation in grains that received N3 or N4 treatments was significantly higher than those in grains under other treatments in 2009 - 2010 and 2011 - 2012. In 2010 - 2011, while dry matter accumulation in grains under $\mathrm{N} 3, \mathrm{~N} 4$, or N5 treatments was significantly higher than those under other treatments, no significant differences were observed between N3, N4, and $\mathrm{N} 5$ treatments. Overall, $\mathrm{N}$ rates of 150 and $180 \mathrm{~kg} \mathrm{ha}$ showed the most prominent effect in enhancing dry matter accumulation in grains, which contributed to improved grain yield. In addition, the effect of $\mathrm{N}$ rate on total above-ground biomass at maturity was similar to that on dry matter accumulation in grains in each growth season.

\section{DMR after anthesis}

The DMR with different $\mathrm{N}$ rates varied in each growth season (Table 3). While DMR was not affected by $\mathrm{N}$ rate in $2009-2010$, it significantly decreased with increasing $\mathrm{N}$ rate up to $150 \mathrm{~kg} \mathrm{ha}^{1}$ in 2010 - 2011. In $2011-2012$, however, DMR significantly increased with increasing $\mathrm{N}$ rate up to $150 \mathrm{~kg} \mathrm{ha}^{1}$ before leveling off at higher $\mathrm{N}$ rates. Meanwhile, DMRE showed a declining trend with increasing $\mathrm{N}$ rate in all three seasons. Our results suggested that the effect of $\mathrm{N}$ rate on DMR is complex. Increasing $\mathrm{N}$ rate does not necessarily promote DMR. It may even reduce DMR under certain conditions.

Dry matter accumulation after anthesis significantly increased with increasing $\mathrm{N}$ rate up to $150 \mathrm{~kg} \mathrm{ha}^{1}$ in all growth seasons. The effect of $\mathrm{N}$ rate differed, however, under $\mathrm{N}$ rates higher than $150 \mathrm{~kg} \mathrm{ha}{ }^{1}$. Dry matter accumulation significantly decreased in $2009-2010$ and 2011 - 2012, whereas it only leveled off in $2010-2011$. The contribution of post-anthesis assimilates to grains under different $\mathrm{N}$ rates ranged from $58.5 \%$ to $80.1 \%$, with the higher ones being obtained at 150 and $180 \mathrm{~kg} \mathrm{ha}^{1}$, suggesting that post-anthesis assimilates were the main source of dry matter accumulation in grains. Taken together, $\mathrm{N}$ rates of 150 and $180 \mathrm{~kg} \mathrm{~N} \mathrm{ha}{ }^{-1}$ were most effective in promoting post-anthesis assimilates and dry matter accumulation in grains and ultimately the grain yield. 
Table 3 DMR (mg culm ${ }^{1}$ ) under different $\mathrm{N}$ treatments during the 2009-2012 growth seasons

\begin{tabular}{|c|c|c|c|c|}
\hline Treatment & $\begin{array}{l}\text { Dry matter } \\
\text { remobilization }\end{array}$ & $\begin{array}{l}\text { Dry matter remobilization } \\
\text { efficiency }(\%)\end{array}$ & $\begin{array}{l}\text { Dry matter accumulaiton } \\
\text { after anthesis }\end{array}$ & $\begin{array}{l}\text { Contribution of } \\
\text { post-anthesis assimilates to } \\
\text { grain }(\%)\end{array}$ \\
\hline \multicolumn{5}{|l|}{$2009-2010$} \\
\hline No & $275.67 \mathrm{c}$ & $21.42 \mathrm{ab}$ & $560.44 c$ & $67.03 \mathrm{ab}$ \\
\hline N1 & $292.00 \mathrm{a}$ & $22.16 \mathrm{a}$ & $588.44 b$ & $66.83 \mathrm{ab}$ \\
\hline $\mathrm{N} 2$ & $298.44 a$ & $22.14 \mathrm{a}$ & $586.89 \mathrm{~b}$ & $66.29 b$ \\
\hline N3 & $299.67 \mathrm{a}$ & $21.19 \mathrm{ab}$ & $690.56 a$ & $69.74 \mathrm{ab}$ \\
\hline N4 & $295.44 a$ & $20.70 b$ & $689.22 \mathrm{a}$ & $70.008 \mathrm{a}$ \\
\hline N5 & $294.11 \mathrm{a}$ & $20.46 \mathrm{~b}$ & $578.78 b c$ & $66.31 \mathrm{~b}$ \\
\hline \multicolumn{5}{|l|}{$2010-2011$} \\
\hline No & $210.67 b$ & $21.05 \mathrm{~b}$ & $453.22 \mathrm{c}$ & $68.27 b$ \\
\hline N1 & $308.22 \mathrm{a}$ & $25.05 \mathrm{a}$ & $553.00 \mathrm{~b}$ & $64.21 \mathrm{c}$ \\
\hline $\mathrm{N} 2$ & $284.67 \mathrm{a}$ & $23.28 \mathrm{ab}$ & $587.89 b$ & $67.38 b c$ \\
\hline N3 & $189.11 \mathrm{c}$ & $14.97 \mathrm{c}$ & $762.67 \mathrm{a}$ & $80.13 \mathrm{a}$ \\
\hline N4 & $194.78 \mathrm{c}$ & $15.59 \mathrm{c}$ & $739.11 \mathrm{a}$ & $79.14 \mathrm{a}$ \\
\hline N5 & $184.67 \mathrm{c}$ & $14.81 \mathrm{c}$ & $731.89 a$ & $79.85 \mathrm{a}$ \\
\hline \multicolumn{5}{|l|}{$2011-2012$} \\
\hline No & $312.44 c$ & $25.55 \mathrm{a}$ & $440.11 d$ & $58.48 \mathrm{c}$ \\
\hline N1 & $331.78 b$ & $23.36 \mathrm{ab}$ & $712.67 \mathrm{~b}$ & $68.23 \mathrm{ab}$ \\
\hline $\mathrm{N} 2$ & $326.89 b c$ & $22.88 \mathrm{~b}$ & $729.00 \mathrm{ab}$ & $69.04 \mathrm{a}$ \\
\hline N3 & $375.11 \mathrm{a}$ & $23.70 \mathrm{ab}$ & $747.78 \mathrm{a}$ & $66.591 \mathrm{ab}$ \\
\hline N4 & $363.44 a$ & $22.89 b$ & $749.11 \mathrm{a}$ & $67.33 \mathrm{ab}$ \\
\hline N5 & $362.44 \mathrm{a}$ & $21.77 \mathrm{~b}$ & $675.22 \mathrm{c}$ & $65.07 \mathrm{~b}$ \\
\hline
\end{tabular}

Values are means over three replicates. Values in the same column with different letters in each growth season are significantly different $(n=3 ; P<0.05)$.

\section{SWC of the $0-200 \mathrm{~cm}$ soil layers at maturity}

$\mathrm{N}$ rate had different effects on SWC of the 10 soil layers $(20 \mathrm{~cm}$ each) at maturity in the three growth seasons (Figure 1). In 2009 - 2010, SWC of soil layers within $120-200 \mathrm{~cm}$ did not vary with $\mathrm{N}$ rate. SWC of soil layers within $0-120 \mathrm{~cm}$ significantly decreased with increasing $\mathrm{N}$ rate up to $150 \mathrm{~kg} \mathrm{ha}^{1}$.
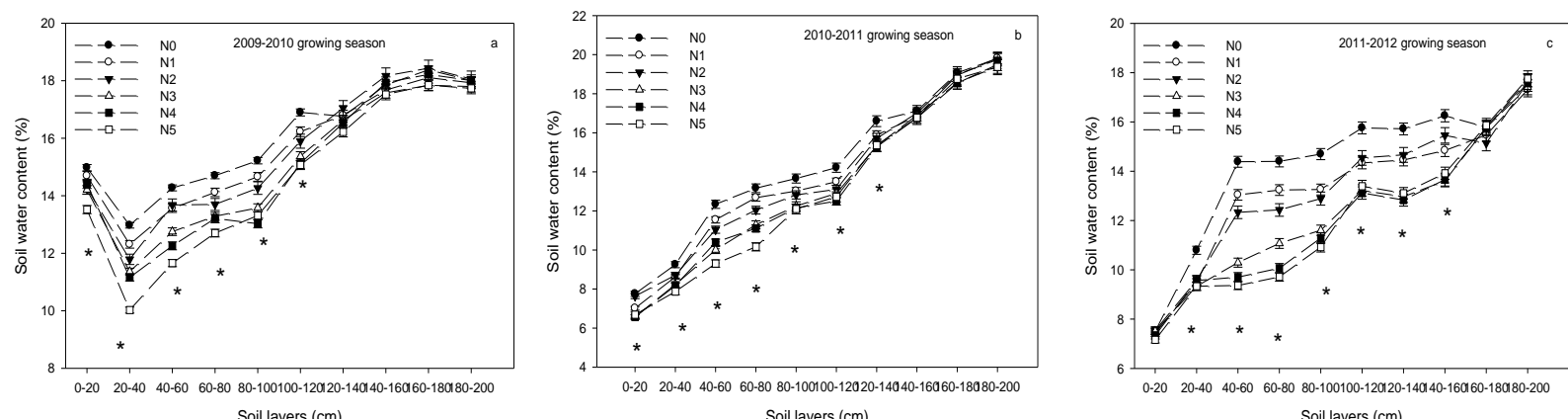

Figure 1. Changes in SWC in $0-200 \mathrm{~cm}$ soil layers at maturity under different $\mathrm{N}$ regimens during the growth seasons in $2009-$ 2010 (a), $2010-2011$ (b), and $2011-2012$ (c). Values are means over three replicates. Bars represent $\square$ SE. The asterisk (*) indicates significant differences between treatments $(P<0.05)$

In addition, SWC of soil layers within $0-80 \mathrm{~cm}$ continued to decline significantly when $\mathrm{N}$ rate was raised from 150 to $210 \mathrm{~kg} \mathrm{ha}^{1}$. In $2010-2011$, SWC of soil layers within $0-140 \mathrm{~cm}$ was significantly lower than that of controls while SWC of soil layers within $140-200 \mathrm{~cm}$ was not affected by $\mathrm{N}$ rate. Particularly, SWC of soil layers within $20-80 \mathrm{~cm}$ significantly decreased with increasing $\mathrm{N}$ rate up to $210 \mathrm{~kg} \mathrm{ha}^{1}$. In $2011-2012$, SWC of soil layers within $20-160 \mathrm{~cm}$ was significantly lower than that of controls. SWC of soil layers within $40-160$ $\mathrm{cm}$ significantly decreased with increasing $\mathrm{N}$ rate up to $150 \mathrm{~kg} \mathrm{ha}{ }^{1}$. Particularly, SWC of soil layers within $40-$
$80 \mathrm{~cm}$ continued the significant declining trend under $\mathrm{N}$ rates above $150 \mathrm{~kg} \mathrm{ha}{ }^{1}$. Taken together, our results indicated that $\mathrm{N}$ rate of $150 \mathrm{~kg} \mathrm{ha}{ }^{1}$ promoted soil water consumption of winter wheat, especially in deep soil layers $(100-160 \mathrm{~cm})$. In most cases, $\mathrm{N}$ rates higher than $150 \mathrm{~kg} \mathrm{ha}{ }^{1}$ did not further promote soil water consumption.

\section{Grain yield and its components}

Grain yield and its components under different $\mathrm{N}$ rates during the 2009 - 2012 growth seasons are shown in Table 4. Grain yields under N3 and N4 treatments were 
significantly higher than those under other treatments in 2009 - 2010 and 2011 - 2012. In 2010 - 2011, grain yield

significantly increased with increasing $\mathrm{N}$ rate up to $150 \mathrm{~kg}$ $\mathrm{ha}^{1}{ }^{1}$ before leveling off. The maximum grain yield was obtained under $\mathrm{N}$ rate of $150 \mathrm{~kg} \mathrm{~N} \mathrm{ha}^{1}$ in all three growth seasons, with the highest grain yield being $7160.8 \mathrm{~kg} \mathrm{ha}$ in 2011 - 2012. Compared with controls, the grain yield under $\mathrm{N} 3$ treatment $\left(150 \mathrm{~kg} \mathrm{ha}^{1}\right)$ increased by $51.4 \%$, $63.0 \%$, and $66.6 \%$ in the three growth seasons, respectively. Our results suggested that $150 \mathrm{~kg} \mathrm{ha}^{1}$ was the optimal nitrogen application rate for wheat grown in the rainfed region investigated.

The number of spikes per square meter was not significantly affected by $\mathrm{N}$ treatments in all growth seasons. However, the number of grains per spike significantly increased with increasing $\mathrm{N}$ rate up to $150 \mathrm{~kg}$ $\mathrm{ha}^{1}{ }^{1}$ before leveling off in $2009-2010$ and $2011-2012$, whereas in 2010 - 2011 the number of grains per spike did not change with $\mathrm{N}$ rates. Grain weight significantly increased with increasing $\mathrm{N}$ rate up to $150 \mathrm{~kg} \mathrm{ha}^{1}$ in all three seasons. Under $\mathrm{N}$ rates above $150 \mathrm{~kg} \mathrm{ha}{ }^{1}$, grain weight declined in 2009 - 2010 and 2011 - 2012 but stayed the same as that obtained under $150 \mathrm{~kg} \mathrm{ha}{ }^{1}$ in 2010 - 2011. These results indicated that $150 \mathrm{~kg} \mathrm{ha}^{1}$ was the optimal $\mathrm{N}$ rate for improving grain number per spike and grain weight.

Table 4 Grain yield and its components under different N treatments during the 2009-2012 growth seasons

\begin{tabular}{|c|c|c|c|c|}
\hline Treatment & $\begin{array}{l}\text { Spike number } \\
\left(\times 10^{4} \mathrm{ha}^{-1}\right)\end{array}$ & $\begin{array}{l}\text { Grain number } \\
\text { per spike }\end{array}$ & $\begin{array}{l}\text { Weight per } 1000 \\
\text { Kernels (g) }\end{array}$ & $\begin{array}{l}\text { Grain yield } \\
\left(\mathrm{kg} \mathrm{ha}^{-1}\right)\end{array}$ \\
\hline \multicolumn{5}{|l|}{$2009-2010$} \\
\hline No & 429.34b & $28.83 \mathrm{c}$ & $32.32 \mathrm{c}$ & $3807.80 \mathrm{c}$ \\
\hline N1 & $573.34 \mathrm{a}$ & $31.67 \mathrm{~b}$ & $33.79 b$ & $5327.90 \mathrm{~b}$ \\
\hline $\mathrm{N} 2$ & $578.67 \mathrm{a}$ & $32.17 \mathrm{~b}$ & $34.13 b$ & $5402.53 b$ \\
\hline N3 & $581.34 \mathrm{a}$ & $33.17 \mathrm{a}$ & $35.43 a$ & $5765.12 \mathrm{a}$ \\
\hline N4 & $584.00 \mathrm{a}$ & $33.33 a$ & $35.25 \mathrm{a}$ & $5718.18 \mathrm{a}$ \\
\hline N5 & $586.67 \mathrm{a}$ & $33.67 \mathrm{a}$ & $33.51 \mathrm{~b}$ & $5445.97 b$ \\
\hline \multicolumn{5}{|l|}{ 2010-2011 } \\
\hline No & 421.34b & $20.38 b$ & $44.94 \mathrm{~b}$ & $2808.10 \mathrm{c}$ \\
\hline N1 & $474.67 \mathrm{a}$ & $23.10 \mathrm{a}$ & $44.96 \mathrm{~b}$ & $4118.43 b$ \\
\hline $\mathrm{N} 2$ & $477.34 \mathrm{a}$ & $23.20 \mathrm{a}$ & $45.10 \mathrm{~b}$ & $4209.12 b$ \\
\hline N3 & $480.00 \mathrm{a}$ & $23.37 \mathrm{a}$ & $46.80 \mathrm{a}$ & $4577.98 \mathrm{a}$ \\
\hline N4 & $485.34 \mathrm{a}$ & $23.44 \mathrm{a}$ & $46.62 a$ & $4541.11 \mathrm{a}$ \\
\hline N5 & $482.67 \mathrm{a}$ & $23.36 \mathrm{a}$ & $46.43 a$ & $4401.79 a$ \\
\hline \multicolumn{5}{|l|}{ 2011-2012 } \\
\hline No & $570.67 b$ & $29.49 \mathrm{c}$ & $30.21 \mathrm{c}$ & $4298.80 c$ \\
\hline N1 & $626.67 \mathrm{a}$ & $32.98 b$ & $33.83 b$ & $6598.32 b$ \\
\hline $\mathrm{N} 2$ & $632.00 \mathrm{a}$ & $33.19 b$ & $33.94 b$ & $6775.26 b$ \\
\hline N3 & $637.34 \mathrm{a}$ & $34.57 \mathrm{a}$ & $35.56 \mathrm{a}$ & $7160.75 a$ \\
\hline N4 & $642.67 \mathrm{a}$ & $34.11 \mathrm{a}$ & $35.40 \mathrm{a}$ & $7152.41 \mathrm{a}$ \\
\hline N5 & $648.00 \mathrm{a}$ & $34.28 \mathrm{a}$ & $34.14 \mathrm{~b}$ & $6753.92 b$ \\
\hline
\end{tabular}

Values are means over three replicates. Values in the same column with different letters in each growth season are significantly different $(n=3 ; P<0.05)$.

Relationships between grain yield, dry matter remobilization and accumulation, and water status

Significant positive linear correlations were found between grain yield and dry matter accumulation, both at and after anthesis (Figure 2). Significant positive correlation between grain yield and DMR was found in $2009-2010$ and $2011-2012$ but not in $2010-2011$. Our data indicated that it may be a useful route for optimizing nitrogen application to achieve high yields by improving both dry matter accumulation at anthesis and post-anthesis assimilates.

Grain yield was found to have a significant relationship with ET when data were fitted to quadratic equations. Similar significant relationships were found between WUE and ET in each growth season (Figure 3). These results suggested that $\mathrm{N}$ rate might be optimized to achieve high grain yields and high WUE simultaneously. 

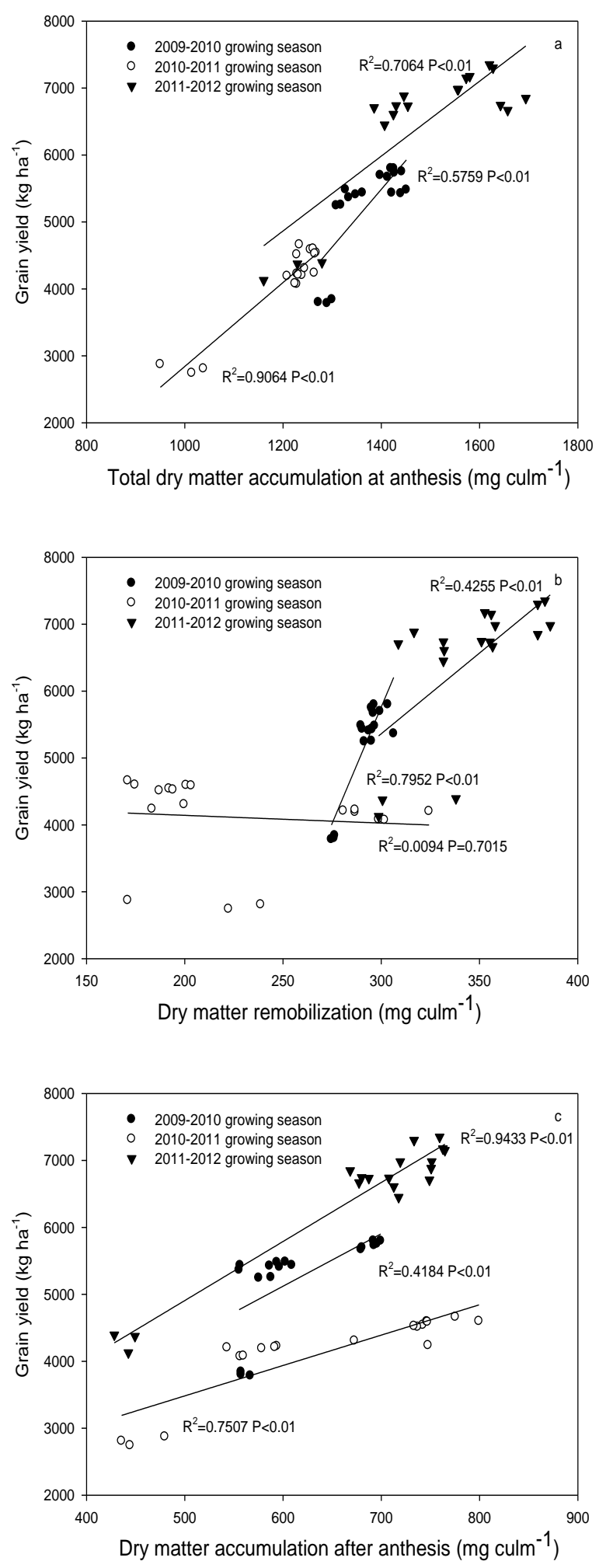

Figure 2. Relationships between grain yield and total dry matter accumulation at anthesis (a), between grain yield and DMR remobilization (b), and between grain yield and dry matter accumulation after anthesis (c) during the $2009-2012$ growth seasons
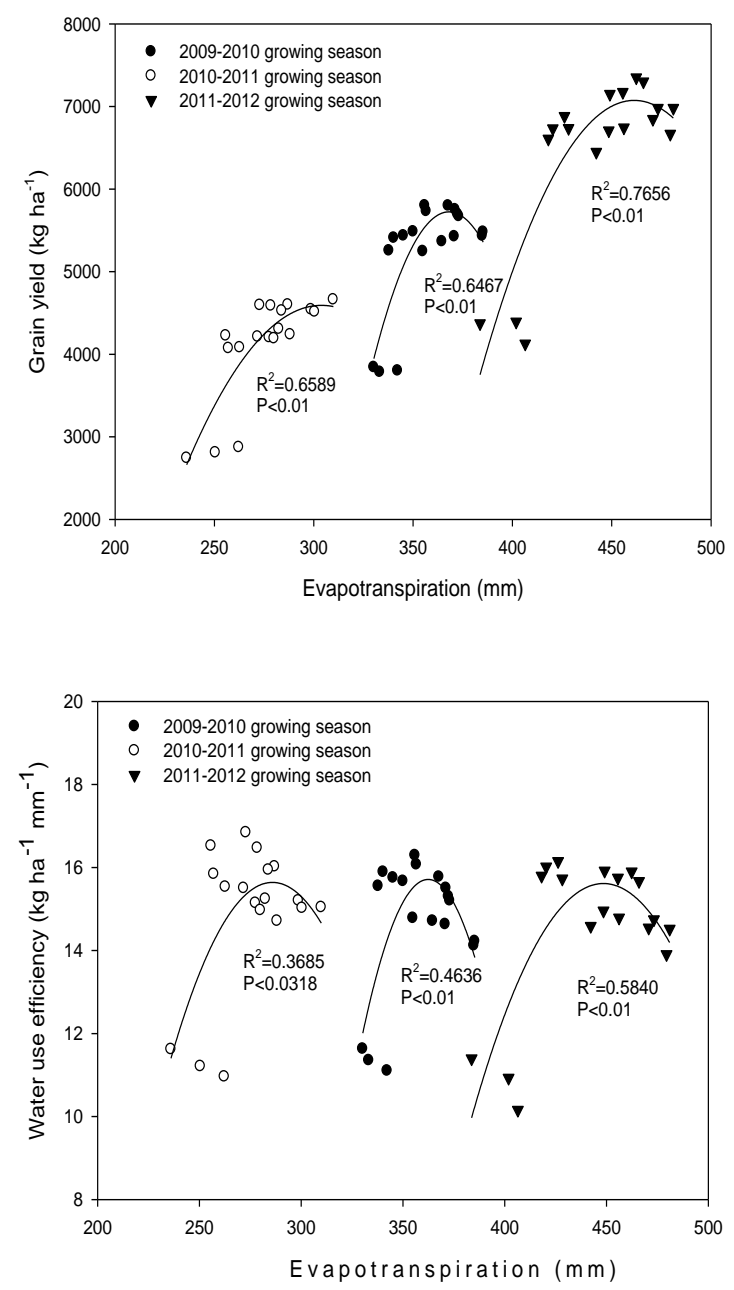

Figure 3 Relationships between grain yield and ET (a), and between WUE and ET (b) during the 2009 - 2012 growth seasons

\section{DISCUSSION}

It has been well established that $\mathrm{N}$ fertilization profoundly affects dry matter accumulation and partitioning in wheat. Garabet et al. (1998) found that N fertilization increased total dry matter accumulation at maturity. Fois et al. (2009) reported that $120 \mathrm{~kg} \mathrm{~N} \mathrm{a}^{1}$ generated significant increases in above-ground dry matter accumulation at both anthesis and maturity. Dordas (2009) demonstrated that the accumulation of dry matter in grain at harvest was similar to that of vegetative parts (leaf, culm, and chaff) as well as that total above-ground biomass at anthesis and that at maturity both increased when the $\mathrm{N}$ application rate was $80 \mathrm{~kg} \mathrm{ha}^{1}$. In the present study, dry matter accumulation and partitioning into different plant parts varied under different $\mathrm{N}$ rates. Increasing $\mathrm{N}$ rate to a certain level was beneficial for improving dry matter accumulation at both anthesis and maturity. In this study, the highest dry matter accumulation in grains was obtained at $150 \mathrm{~kg} \mathrm{~N} \mathrm{ha}^{{ }^{1}}$ in all growth seasons. 
DMR can be affected by cultivars and prevailing growth conditions (Papakosta and Gagianas, 1991). Ma et al. (2007) showed that DMR first increased and then decreased with increasing $\mathrm{N}$ rate. In particular, DMRE in wheat was found to range from $10.2 \%$ to $23.4 \%$ under different $\mathrm{N}$ rates (Ma et al., 2007; Bahrani et al., 2011). In the present study, DMR was affected by $\mathrm{N}$ rate differently in different growth seasons. DMR increased with increasing $\mathrm{N}$ rate up to a certain level but excessive $\mathrm{N}$ rates did not help promoting DMR further. Meanwhile, values of DMRE, which ranged from $14.8 \%$ to $25.6 \%$, were slightly higher than those reported previously, likely attributed to differences in cultivars and weather conditions. According to Zou et al. (2011), when nitrogen levels in soil were in the range of $225-300 \mathrm{~kg} \mathrm{ha}^{1}$, wheat grain yield was mainly determined by photosynthetic assimilation of green organs after anthesis followed by distribution of dry matter accumulation before anthesis. Ercolia et al. (2008) found that post-anthesis dry matter accumulation under $180 \mathrm{~kg} \mathrm{~N}$ ha ${ }^{1}$ was significantly higher than that under $120 \mathrm{~kg} \mathrm{~N} \mathrm{ha}{ }^{1}$. The contribution of post-anthesis assimilates to grains was reported to range from $53.6 \%$ to $82.4 \%$ under different $\mathrm{N}$ rates in wheat ( $\mathrm{Lu}$ et al., 2007). In the present study, the contribution of post-anthesis assimilates to grains with different $\mathrm{N}$ rates ranged from $64.2 \%$ to $80.1 \%$. These data suggested that dry matter accumulation after anthesis was a main source of dry matter accumulation in grains. $\mathrm{N}$ rate of $150 \mathrm{~kg} \mathrm{ha}$ enhanced post-anthesis dry matter accumulation and thus its contribution to grain yield, leading to higher grain production.

Soil water storage after wheat harvest has been reported to be lower under $\mathrm{N}$ fertilizer treatments compared with unfertilized treatments (Latiri-Souki et al., 1998; Angus and Herwaarden, 2001). In contrast, Gentile et al. (2005) found that $\mathrm{N}$ rates did not consistently affect seasonal soil water consumption in soils with adequate $\mathrm{N}$ supply. In the present study, $\mathrm{N}$ fertilizer application was found to improve soil water consumption. Patterns of soil

water profile for control and $\mathrm{N}$ fertilized treatments are generally similar, and SWCs with significant differences in soil layers with $\mathrm{N}$ application rates may vary during different growth seasons (Corbeels et al., 1998). Similar results were obtained in the present study, with significant changes in SWCs being found in soil layers within 0 $160 \mathrm{~cm}$ under different $\mathrm{N}$ rates in the third growth season. Xie et al. (2011) reported that SWC of soil layers within $80-200 \mathrm{~cm}$ was not affected by increasing $\mathrm{N}$ rate up to $165 \mathrm{~kg} \mathrm{ha}{ }^{1}$ in the rainfed area of South Shanxi Province, China. In addition, Wang et al. (2007) reported that in soils supplied with $90 \mathrm{~kg} \mathrm{~N}$ ha $^{1}$ in the dryland of Loess Plateau, soil moisture contents in soil layers within $100-$ $200 \mathrm{~cm}$ stayed stable. In the present study, SWC of deep soil layers $(100-200 \mathrm{~cm})$ did not change significantly with increasing $\mathrm{N}$ rate when the $\mathrm{N}$ rates were above 150 $\mathrm{kg} \mathrm{ha}{ }^{1}$.

Santiveri et al. (2004) reported that higher dry matter at anthesis was associated with higher yield in spring triticale. Ehdaie and Waines (2001) showed that grain yield was positively correlated with shoot biomass at anthesis in bread and durum wheat. Bahrani et al. (2011) found that grain yield was positively related to dry matter at anthesis in winter wheat grown in dryland. In the present study, significant positive linear correlations were found between grain yield and dry matter accumulation, both at and after anthesis. We also found that the relationship between grain yield and DMR varied in different growth seasons, in alignment with previous results reported by Przulj and Momcilovic (2001). It has been shown that quadratic functions were more suitable for analysis of relationships between seasonal ET and grain yield or WUE (Li et al., 2005; Zhang et al., 2005; Kang et al., 2002). In our analysis using quadratic functions, we found that grain yield and WUE had similar relationships with ET.

In the present study, three different cultivars were used among different growth seasons, which may make some effects in the analysis of the results among different growth seasons. Long-term effects of nitrogen fertilization on individual cultivar require further study to provide more reliable guidance for nitrogen management in the said region. According to Knaggs (2002), N additions had little effect on crop biomass or grain yield in soils that already had a high $\mathrm{N}$ supply. Further studies should be conducted to investigate whether or not the amount of applied nitrogen can be decreased without reducing crop yield after high $\mathrm{N}$ fertilizer rates have been applied for several years.

\section{CONCLUSION}

This study examined the effects of six levels of nitrogen fertilization on dry matter accumulation, remobilization, and SWCs in a rainfed winter wheat field in three growth seasons in Shandong Province of China. Nitrogen fertilization increased dry matter accumulation, both at anthesis and at maturity, and promoted post-anthesis assimilates. Dry matter accumulation in grains, total above-ground biomass at maturity, and post-anthesis assimilates all increased with increasing $\mathrm{N}$ rate up to $150 \mathrm{~kg} \mathrm{ha}^{1}$ in all growth seasons. Under $\mathrm{N}$ rates higher than $150 \mathrm{~kg} \mathrm{ha}^{1}$, dry matter accumulation at anthesis and maturity, DMR, and post-anthesis assimilates did not appear to add up in all growth seasons. Application of $150 \mathrm{~kg} \mathrm{~N} \mathrm{ha}^{1}$ also promoted soil water consumption of winter wheat, especially in deep soil layers $(100-160$ $\mathrm{cm})$. SWC of deep soil layers did not change significantly with increasing $\mathrm{N}$ rate under $\mathrm{N}$ rates above $150 \mathrm{~kg} \mathrm{ha}{ }^{1}$, suggesting that the capability of $\mathrm{N}$ fertilization to promote soil water consumption was saturated under high $\mathrm{N}$ rates. The maximum grain yield was obtained under $150 \mathrm{~kg} \mathrm{~N}$ $\mathrm{ha}^{1}{ }^{1}$ in all growth seasons, with the highest being 7160.6 $\mathrm{kg} \mathrm{ha}^{1}$ in the $2011-2012$ growth season. These results were in alignment with our expectations considering that dry matter accumulation and soil water consumption are two key factors contributing to grain yield. Our results suggested that $150 \mathrm{~kg} \mathrm{ha}{ }^{1}$ may be the optimal $\mathrm{N}$ 
application rate for high grain yield of winter wheat in the rainfed region in Shandong Province of China.

\section{ACKNOWLEDGMENTS}

This study was supported by the National Natural Science Foundation of China (31171498) and Technology System in Modern Wheat Industry, Chinese Ministry of Agriculture (CARS-3-1-19). We thank the Agricultural Bureau of Linzi District for providing meteorological data.

\section{LITERATURE CITED}

Angus, J.F., A.F. Herwaarden. 2001. Increasing water use and water use efficiency in dryland wheat. Agron J. 93: 290-298.

Arduini, I., A. Masoni, L. Ercoli, M. Mariotti. 2006. Grain yield, and dry matter and nitrogen accumulation and remobilization in durum wheat as affected by variety and seeding rate. Eur $\mathbf{J}$. Agron. 25: 309-318.

Austin, R.B., C.L. Morgan, M.A. Ford, R.D. Blackwell. 1980. Contribution to grain yield from pre-anthesis assimilation in tall and dwarf barley phenotypes in two contrasting seasons. Ann Bot. 45: 309-319.

Bahrani, A., H.H. Sharifabad, Z.T. Sarvestani, G.H. Moafpourian, A.A. Band. 2011. Remobilization of dry matter in wheat: effects of nitrogen application and post-anthesis water deficit during grain filling. New Zeal J. Crop Hort Sci. 39: 279-293.

Basso, B., D. Cammarano, A. Troccoli, D.L. Chen, J.T. Ritchie, 2010. Long-term wheat response to nitrogen in a rainfed Mediterranean environment: Field data and simulation analysis. Eur J. Agron. 33: 132-138.

Chen H.L., X.H. Tian, X.F. Wang, Y.X. Cao, Y.H. Wu, Z.H. Wang. 2010. Effects of cultivation models on soil water, soil temperature and yield during the winter wheat growth in the Weibei dry highland. Acta Ecol Sin. 30: 2424-2433.

Corbeels, M., G. Hofman, O.V. Cleemput. 1998. Analysis of water use by wheat grown on a cracking clay soil in a semi-arid Mediterranean environment: weather and nitrogen effects. Agr Water Manage. 38: 147-167.

Dordas, C. 2009. Dry matter, nitrogen and phosphorus accumulation, partitioning and remobilization as affected by $\mathrm{N}$ and $\mathrm{P}$ fertilization and source-sink relations. Eur J. Agron. 30: $129-139$

Ehdaie, B., J.G. Waines. 2001. Sowing date and nitrogen rate effects on dry matter and nitrogen partitioning in bread and durum wheat. Field Crops Res. 73: 47-61.

Ercolia, L., L. Lullib, M. Mariottib, A. Masonib, I. Arduini. 2008. Post-anthesis dry matter and nitrogen dynamics in durum wheat as affected by nitrogen supply and soil water availability. Eur J. Agron. 28: 138-147.

Ferrise, R., A. Triossi, P. Stratonovitch, M. Bindi, P. Martre. 2010. Sowing date and nitrogen fertilisation effects on dry matter and nitrogen dynamics for durum wheat: An experimental and simulation study. Field Crops Res. 117: 245-257.

Fois, S., R. Motzo, F. Giunta. 2009. The effect of nitrogenous fertiliser application on leaf traits in durum wheat in relation to grain yield and development. Field Crops Res. 110: 69-75.

Gan, Y.T., G.P. Lafond, W.E. May. 2000. Grain yield and water use: Relative performance of winter vs. spring cereals in east-central Saskatchewan. Can J. Plant Sci. 80: 533-541.

Garabet, S., M. Wood, J. Ryan. 1998. Nitrogen and water effects on wheat yield in a Mediterranean-type climate I. Growth, water-use and nitrogen accumulation. Field Crops Res. 57: 309-318.
Gentile, R.M., P.J. de Rocquigny, M.H. Entz. 2005. Soil water depletion by tall and semidwarf oat and wheat cultivars. Can J. Plant Sci. 85: 385-388.

Halvorson, A.D., D.C. Nielsen, C.A. Reule. 2004. Nitrogen fertilization and rotation effects on no-till dryland wheat production. Agron J. 96: 1196-1201.

Hao, M.D., J. F, Q.J.Wang, T.H. Dang, S.L. Guo, J.J. Wang. 2007. Wheat grain yield and yield stability in a long-term fertilization experiment on the Loess Plateau. Pedosphere. 17 257-264.

Hassan, M.I., A.M. Badreldin. 1996. Phasic development of spring wheat and stability of yield and its components in hot environments. Field Crops Res. 46: 169-176.

Holger, M., L.H. Graeme, V.K. Herman, R. Rudy, A.K. Brian. 1997. Improving wheat simulation capabilities in Australia from a cropping systems perspective: water and nitrogen effects on spring wheat in a semi-arid environment. Eur J. Agron. 7: 75-88.

Hossein, S., J.B. Mohammad. 2009. Effects of crop residue and nitrogen rates on yield and yield components of two dryland wheat (Triticum aestivum L.) cultivars. Plant Prod Sci. 12: 497-502.

Kang, S.Z., L. Zhang, Y.L. Liang, X.T. Hu, H.J. Cai, B.J. Gu. 2002. Effects of limited irrigaiton on yield and water use efficiency of winter wheat in the Loess Plateau of China. Agr Water Manage. 55: 203-216.

Knaggs, P.J. 2002. Yield physiology, quality and soil water dynamics of a semidwarf and a tall oat (Avena sativa L.) cultivar. M.Sc. thesis, University of Manitoba, Winnipeg, MB. 168 pp.

Latiri-Souki, K., S. Nortcliff, D.W. Lawlor. 1998. Nitrogen fertilizer can increase dry matter, grain production and radiation and water use efficiencies for durum wheat under semi-arid conditions. Eur J. Agron. 9: 21-34.

Li, J.M., S. Inanag, Z.H. Li., A.E.Eneji. 2005. Optimizing irrigation scheduling for winter wheat in the North China Plain. Agr Water Manage. 76: 8-23.

Li T.L., Y.H. Xie, M.M. Ren, S.Y. Deng, J. Shan, Z.Y. Lei, J.P. Hong, C H Wang. 2011. Effects of fertilization and plastic film mulched ridge-furrow cultivation on yield and water and nitrogen utilization of winter wheat on dryland. Acta Ecol Sin. 31: 212-220.

Li, Y.Y., Y.J. Guo, M.A. Shao. 2000. The effect of fertilizer application on the growth and development and water use of winter wheat in hilly land of west Henan. Agric Res Arid Areas. 18: 15-21.

Li, Z.Z., W.D. Li, W.L. Li. 2004. Dry-period irrigation and fertilizer application affect water use and yield of spring wheat in semi-arid regions. Agr Water Manage. 65: 133-143.

Lu, Z.G., T.B. Dai, D. Jiang, Q. Jing, Z.G.Wu, P.N. Zhou, W.X Cao. 2007. Effects of nitrogen strategies on population quality index and grain yield and quality in weak-gluten wheat. Acta Agron Sin. 33: 590-597.

Ma, D.H., Y.F. Wang, H. Zhou, H. Sun. 2007. Effect of post-anthesis soil water status and nitrogen on grain yield and canopy biomass accumulation and transportation of winter wheat. J. Triticeae Crops. 27: 847-851.

Mainard, S.D. and M.H. Jeuffroy. 2001. Partitioning of dry matter and nitrogen to the spike throughout the spike growth period in wheat crops subjected to nitrogen deficiency. Field Crops Res. 70: 153-165.

Ministry of Agriculture of the People's Republic of China. 2010. China Agriculture Statistical Report. China Statistics Press, Beijing, China. pp, 26.

Miranzadeh, H., Y. Emam, P. Pilesjö, H. Seyyedi. 2011. Water use efficiency of four dryland wheat cultivars under different levels of nitrogen fertilization. J. Agr Sci Tech. 13: 843-854. 
Papakosta, D.K. and A.A. Gagianas. 1991. Nitrogen and dry Matter Accumulation, remobilization, and losses for Mediterranean wheat during grain filling. Agron J. 83: 864-870.

Pheleung, P.C. and K.H.M. Siddique. 1991. Contribution of stem dry matter to grain yield in wheat cultivars. Aust J. Plant Physiol. 18: 53-64.

Przulj, N. and V. Momcilovic. 2001. Genetic variation for dry matter and nitrogen accumulation and translocation in two-rowed spring barley I. Dry matter translocation. Eur J. Agron. 15: 241-254.

Ryan, J., M. Abdel Monem, J.P. Shroyer, M. El Bouhssini, M.M. Nachit. 1998. Potential for nitrogen fertilization and Hessian fly-resistance to improve Morocco's dryland wheat yields. Eur J. Agron. 8: 153-159.

Ryan, J., R. Sommer, H. Ibrikci. 2012. Fertilizer best management practices: A perspective from the dryland West Asia-North Africa region. J. Agron Crop Sci. 198: 57-67.

Santiveri, F., C. Royo, I. Romagosa. 2004. Growth and yield responses of spring and winter triticale cultivated under Mediterranean conditions. Eur J. Agron. 20: 281-292.

Schnyder, H. 1993. The role of carbohydrate storage and redistribution in the source-sink relations of wheat and barley during grain filling a review. New Phytol. 123: 233-245.

Timsina, J., U. Singh, M. Badaruddin, C. Meisner, M.R. Amin. 2001. Cultivar, nitrogen, and water effects on productivity, and nitrogen-use efficiency and balance for rice-wheat sequences of Bangladesh. Field Crops Res. 72: 143-161.

Villegas, D., J. Casadesus, S.G. Atienza, V. Martos, F. Maalouf, F. Karame, I. Aranjuelo, S. Nogues. 2010. Tritordeum, wheat and triticale yield components under multi-local mediterranean drought conditions. Field Crops Res. 116: 68-74.

Wang, B., W.Z. Liu, T.H. Dang, C.Q. Gao, Z. Li, Z.T. Gan. 2007. Distribution features of soil water content in the profile of rainfed cropland with long-term fertilization. Plant Nutr Fert Sci. 13: 411-416.

Wang D., Z.W. Yu, Y.L. Zhang. 2007. Meteorological conditions affecting the quality of strong-gluten and medium-gluten wheat and climate division in Shandong Province. Chin J. Appl Ecol. 18: 2269-2276.

Wang F.Y., W.J. Feng, S.Y. Liu, Z.C. Wang, L. Mei, Y. Tang. 2013. Research and development of weather risk assessment model group for wheat in Shandong Province. Chin Agri Sci Bull. 29: 197-204.

Wang, G.L., Y.L. Ye, H.H. Li, Y.J. Zhu. 2010. Effect of nitrogen fertilizer application on grain yield and dry matter accumulation for different genotypes of winter wheat. J. Triticeae Crops. 30: 116-122.

Wang, Y.F., J.L. Cheng, B.J. Wang, Y.G. Wang, L.L. Wang, C.Q. Sui. 2003. Review and outlook to the production and development of wheat in dryland of Shandong. J. Laiyang Agric Coll. 20: 200-205.

Xie, Y.H., T.L. Li, J.P. Hong, L.Q. Liu, J. Pang, Q. Feng, S.Y. Deng, J. Shan. 2011. Effects of nitrogen application and ridge film furrow planting on water use of winter wheat in dryland of South Shanxi. Chin. J. Appl Ecol. 22: 2038-2044.

Xu, Z.Z., Z.W. Yu, D. Wang, Y.L. Zhang. 2005. Nitrogen accumulation and translocation for winter wheat under different irrigation regimes. J. Agron. Crop Sci. 191: 439-449.

Xue, Q.W., Z.X. Zhu, J.T. Musick, B.A. Stewart, D.A. Dusek. 2006. Physiological mechanisms contributing to the increased water-use efficiency in winter wheat under deficit irrigation. J. Plant Physiol. 163: 154-164.

Yule, D.F. 1984. Volumetric calculations in cracking clay soils. In: McGarity, J.W., Hoult, E.H., So, H.B. (Eds.), Properties and Utilization of Cracking Clay Soils. Reviews in Rural Science, vol. 5, University of New England, Armidale, NSW, Australia, pp. 136-140.

Zhang, B.C., F.M. Li, G.B. Huang, Y. Gan, P.H. Liu, Z.Y. Cheng. 2005. Effects of regulated deficit irrigation on grain yield and water use efficiency of spring wheat in an arid environment. Can J. Plant Sci. 85: 829-837.

Zhang, J.H., J.L. Liu, J.B. Zhang, F.T. Zhao, Y.N. Cheng, W.P. Wang. 2010. Effects of nitrogen application rates on translocation of dry matter and utilization of nitrogen in rice and wheat. Acta Agron Sin. 36: 1736-1742.

Zhang, M., D. Jiang, R.L. Miao, K. Xu, Y.Y. Liu, J. Zhang, H.C. Zang. 2010. Effects of different soil fertility levels and N application rate on wheat yield and matter production after rice. J. Triticeae Crops. 30: 330-336.

Zou, B., Z.R. Dong, J.S. Wang, J. Zhang, J. Tan, X.G. Xu, Y. Liu, X.W. Li. 2011. Response of post-anthesis assimilates remobilization and yield to nitrogen management in wheat cultivar with different spike-types. Chin Agric Sci Bull. 27: 63-67. 